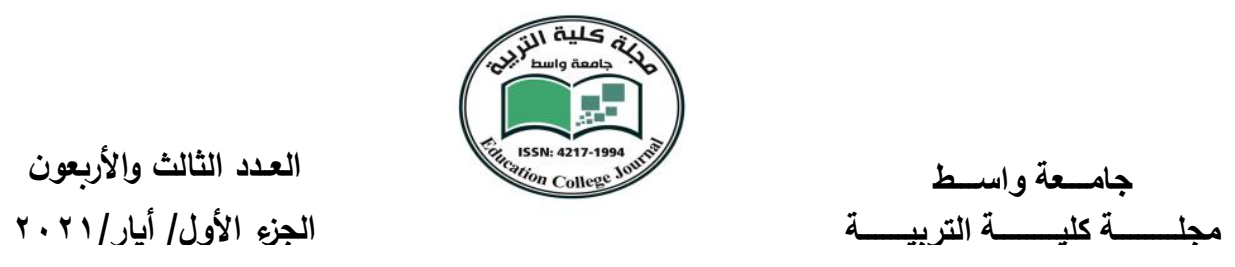

The Difficulties that Teachers Face When Implementing Communicative Language Teaching (CLT) in Secondary Schools in Iraq

\author{
Lecturer:Nawal Hussein Lafta \\ College of Arts/University of Thi-Qar \\ :nawal1967@gmail.com; nawalhussein@utq.edu.iq
}

\begin{abstract}
The main objective of this study is to analyse the difficulties that teachers face when adopting communicative language approach and examining the methodologies they use when teaching English as a Second Language in secondary schools in Iraq. Throughout this analysis, we will be able to enhance students' ability to study the English language correctly and without fear or hesitation. The research was carried out in secondary schools located in Thi-Qar city in the south of Iraq, with a sample comprising 20 male and 10 female teachers. Moreover, a questionnaire with fifteen items was implemented to identify the difficulties faced from the perspective of English teachers. Thirteen teachers confirmed the assertion that the difficulties presented in the questionnaire played an important role in lack of teaching. Key words: communicative language teaching (CLT), English as a foreign language (EFL), applied linguistics

\section{الصعوبات التي يواجهها المدرسين عند تطبيق طريقة التواصل اللغوي في المدارس الثانوية في العرلق تطبيق طريقه}

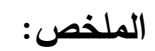

الهدف الرئيسي في هذه الدراسه هو تحليل الصعوبات التي يواجهها المدرسين عند تطبيق طريقة التواصل اللغوي ودراسة الطرق المستخدمة من قبلهم لتدريس اللغه الانكليزية كلغه اجنبية في

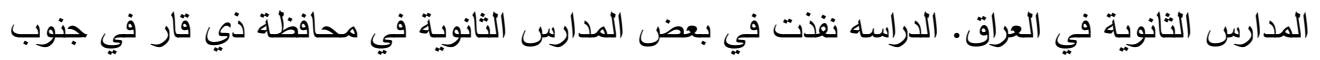

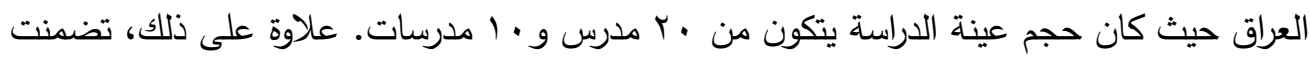

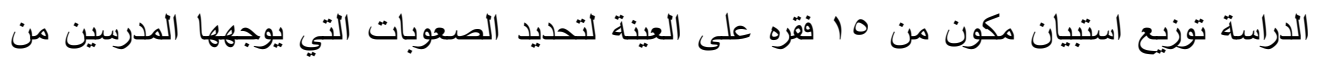




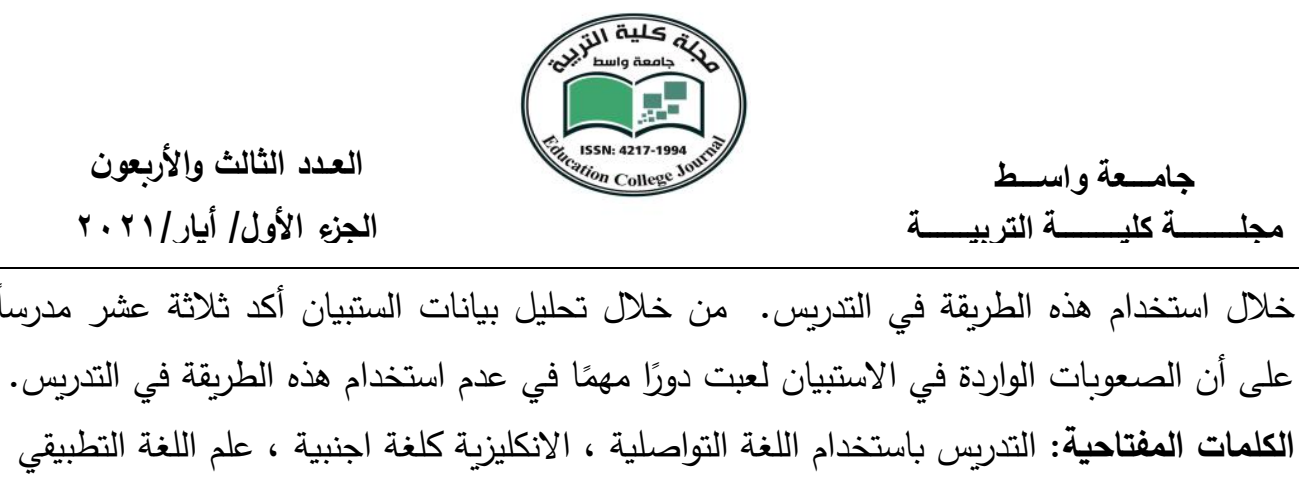

\section{1-Introduction}

The ever-growing need for good communication skills in English has created a huge demand for English teaching around the world. Millions of people today want to improve their command of English or to ensure that their children achieve a good command of the language. Opportunities to learn English are provided in many different forms, such as through formal instruction, travel, studying abroad, as well as through the media and the Internet (Richards, 2006, p1).

The interest in foreign language teaching and learning has expanded around the world owing to globalisation, which is underpinned by the digital era and migratory movements (Paulista \& Gomez, 2014, p5). Linguists and applied linguists have viewed language differently at different times. It has been thought of variously, as a system, as a skill and as a means of communication. In most western countries, the Grammar Translation Method and Structural Approach is utilised for teaching English as a second language. In Iraq English, language is a subject taught from elementary school onwards and whilst it is evident that students experience difficulty with communication in English outside classroom, teachers also feel uncomfortable with the subject in the classroom. This is due to such matters as the lack of teachers who know how to practice CLT, lack of appropriated teaching/learning materials and the problems with big class sizes, As a consequence, learners have been encountering severe barriers to learning in communicative language classrooms.

\subsection{DEFINITION OF COMMUNICATIVE LANGUAGE TEACHING}

Communicative language teaching (CLT),

or

the communicative approach, is a method of language teaching that emphasises interaction as both the means and the ultimate goal of study. According to CLT, the objective of language education is the ability to 


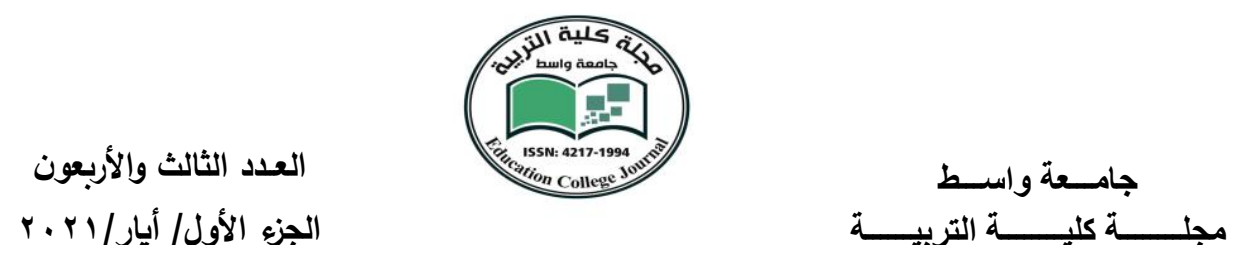

communicate in the target language. It originated in Britain in the 1960s as a replacement to the earlier structural method.

Widdowson (1990, p.159) described the Communicative Approach as follows: “...it concentrates on getting learners to do things with language, to express concepts and to carry out communicative acts of various kinds." The content of a language course is now defined not in terms of forms, words and sentence patterns, but in terms of concepts, or notions, which such forms are used to express, and the communicative functions that they are used to perform. As abovementioned, (CLT) is an approach to the teaching of second and foreign languages that emphasises interaction as both the means and the ultimate goal of learning a language. It pertains to a set of principles about teaching, including recommendations about method and syllabus, where the focus is on meaningful communication and not structure. That is, under this approach, students are given tasks to accomplish using language instead of studying its structure (glossary/communicative approach). Zhang (2006) also held that, ultimately, successful language learning experiences are created through interactive and meaningful communication. Explaining why communicative competence was one of his teaching principles, Brown (2007) argued that this is the 'goal' of language classrooms and should be achieved by constant and extensive language use.

According to Prieto (2008), at the time of undertaking teaching practice, teachers should adopt the attitude of being on element of the class, rather than the main one. That is, the teacher should conceive of the teachinglearning process as a community matter, in which all members of the group should participate. In this way, Prieto claims that: "communication between the students and the teacher will be enhanced, resulting in greater interaction and, certainly, a greater quality in the formative process of the group as a whole." (Prieto, 2008: 334). Larsen-Freeman (2000) stated that communicative competence is the main objective of teaching any language, thereby recognising the interdependence of communication and language. Understanding learners' beliefs is quintessential to ensuring that they receive the quality education they desire. The CLT approach emphasises a change in the role of the teacher from being a transmitter of knowledge to a facilitator of language learning. Teachers must, therefore, develop and utilise teaching 
العدد الثالث والأربعون

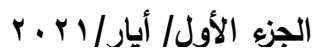

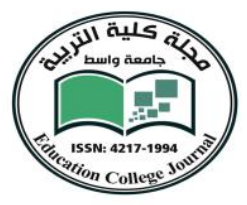

strategies that enable learners to interact freely in a classroom environment, with the purpose being to enhance the required communicative competences (Sekiziyivu and Mugimu, 2017). As observed by Snow (1996), learners effectively learn a language when they take part actively in its communication, rather than just passively accepting what the teacher says. Akram and Mehmood (2011: 175) report an experimental study conducted to ascertain the importance of introducing the communicative approach in ELT in teacher training programmes in Pakistan. They explain that CLT enhances the learners' confidence and it gives a sense of satisfaction to the teacher as well in the sense that s/he is successful in making the students use the foreign language in their conversation.

\subsection{CHARACTERISTICS AND PRINCIPLES OF CLT}

CLT has become popular and widespread in second foreign language teaching (Brown, 1994). Contrary to the teacher-centred approach, in which teachers are regarded as knowledge-givers and learners as receivers, it reflects a more social relationship between the teacher and learner. This learner-centred approach gives students a greater sense of "ownership" of their learning and thus, enhances their motivation to learn English (Brown, 1994). CLT emphasises the process of communication and directs learners towards roles different to the traditional approach. The role of the learner is as a negotiator between the self, the learning process, and the object of learning. Teachers also take on new roles under this approach. First, they facilitate the communication process amongst all participants in the classroom. The teacher is also a co-communicator, who engages in communicative activities with the students (Larsen-Freeman, 2000). Finally, the teacher acts as analyst, counsellor, and group process manager (Richards \& Rodgers, 1986).

\subsection{LITERATURE REVIEW}

The issue of CLT has been widely studied by many researchers. Bataineh, Bataineh, and Thabet, (2011) investigated Yemeni EFL teachers' knowledge of the major principles of CLT and their classroom adherence to these principles. Their findings show that, whilst these teachers were fairly knowledgeable of the principles of CLT, their classroom behaviour did not always reflect this, which was most evident in their tendency to resort to 
العدد الثالث والأربعون

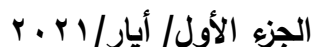

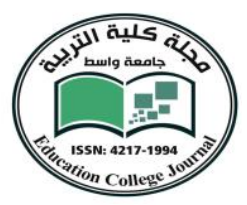

structure-based practices. Hiep (2005) defined the theoretical essentials of CLT and explained the issues that commonly arise when CLT theory is put into practice. He provided suggestions aimed at helping EFL teachers in nonWestern settings to develop appropriate CLT practices for their classrooms. In addition, he called for the need to redefine CLT to accommodate the theory for differing local conditions. Chang (2011) compared the controllability and feasibility of CLT with grammar translation approaches to ascertain what was more suitable for grammar teaching in Taiwan. His results showed that grammar teaching using the framework of the Grammar Translation Method is better than the Communicative Approach. Abdul Wajid and Saleem (2017) explored the opinions of a small group of learners of English at a university to measure their conformity behaviour, and its level, towards CLT in Saudi Arabia. The results of the study showed that learners displayed a high level of conformity behaviour to the CLT activities carried out in English classes.

Haung (2016) used a mixed methodological approach of quantitative surveys and qualitative interviews to uncover the difficulties that rural EFL teachers encountered when implementing CLT in their classrooms. The results of the study revealed that they faced various problems, including students' low L1 cognitive resources and parents' indifferent attitudes toward communicative-English education. Sekiziyivu and Mugimu (2017) explained the teaching strategies that teachers of German used to create a supportive environment for communicative language teaching and learning using a cross sectional survey research design. Questionnaires, observations, and semistructured interviews were used to gather data on teachers' experiences regarding the strategies used to support the CLT approach. Their findings revealed that the teaching strategies utilised by these teachers of German had very little bearing on the CLT approach are relevant to the CLT approach during their pre-and in-service training.

Mangaleswaran and Abdul Aziz (2019) elicited teachers and students' perceptions on the implementation of CLT in the SBELC (Standards-Based English Language Curriculum) as being an effective approach to enhancing students speaking skills. Mustapha and Yahaya (2013) investigated teachers' pedagogical approaches to implementing CLT in classroom practices in 
العدد الثالث والأربعون

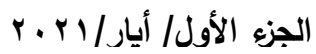

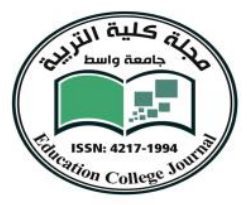

selected community colleges in Malaysia. The study provided insights into teachers' knowledge on CLT as well as the methods and techniques employed by them, which were reflected in their actual classroom practices. Wei, Lin and Litton (2018) probed CLT in the English as a Foreign Language (EFL) context in Asia and China, in particular. They found that CLT has not been fully acknowledged and espoused by Asia's English language educators at the classroom level. They argued that teachers should be constructors rather than merely receivers of the imposed pedagogical reforms.

\subsection{ROLE OF THE TEACHERS IN CLT}

Under the CLT approach, the teacher plays quite a different role than in traditional teaching, being no more the sole knowledge giver in the class. She must takes up the roles of facilitator of learning, analyst of the language used, organiser, and manager of the activities in the class. Littlewood (1981) describes the various roles of the teacher using CLT as: "coordinator of the activities", "classroom manager", "language instructor", "consultant", "advisor" and/or "co-communicator" (p.92-93). Hence, it is clear that the teacher should not be dominant in the class.

\subsection{The purpose of the study}

The aim is to explore the difficulties that teachers encounter when using CLT to teach in secondary levels' classroom and to propose solutions to these. We want to encourage teachers to use this approach in the future when teaching English as a foreign language in secondary schools. By so doing, the aim is to reduce the anxiety and hesitation of students in speaking English language.

This quantitive research is aimed at identifying the difficulties that teachers face when implementing CLT in secondary level classrooms. Evidence shows that after completing many years learning English at school most students are not able to use the language effectively in outside settings. A quantitive approach also allowed us to hear the teachers' voices regarding how they viewed the difficulties they faced when pursuing the implementation of CLT. 


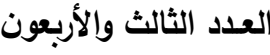

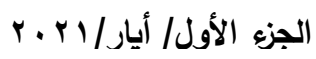

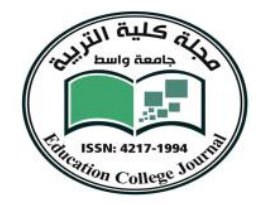

\section{THE METHODOLOGY}

\subsection{Participants}

The participants who took part in this study were 30 Iraqi teachers of English language from public and private secondary schools in Iraq. Specifically, they were chosen randomly from schools in Thi-Qar city. All of them were experienced teachers and most had attended several of workshops concerning ELT delivered by the Ministry of Education in Iraq. As aforementioned, the participants comprised 20 male and 10 female teachers. In the sample, three were aged from 25 to 34,21 were aged 35 to 44 and six were aged 54 or over. In terms of years of teaching experience, three had less than 10 years, 18,11 to 20 years and nine teachers had 21 to 30 years. In regard to qualifications, 26 teachers had a bachelor's degree in English Language teaching, whilst four had masters degrees.
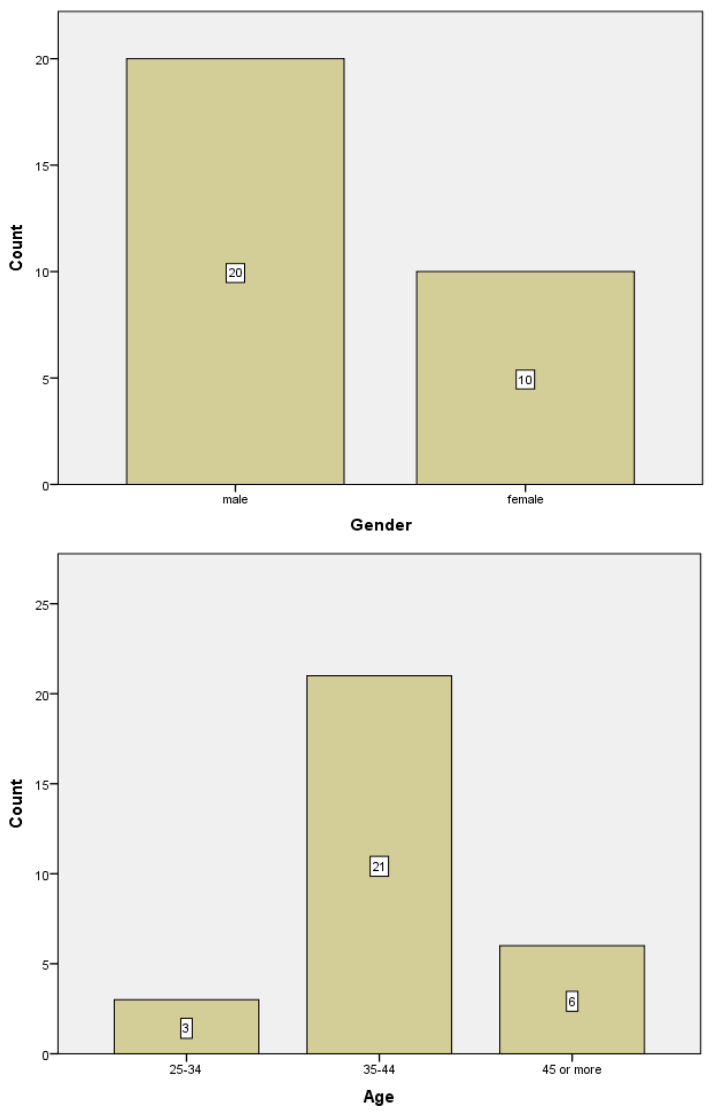


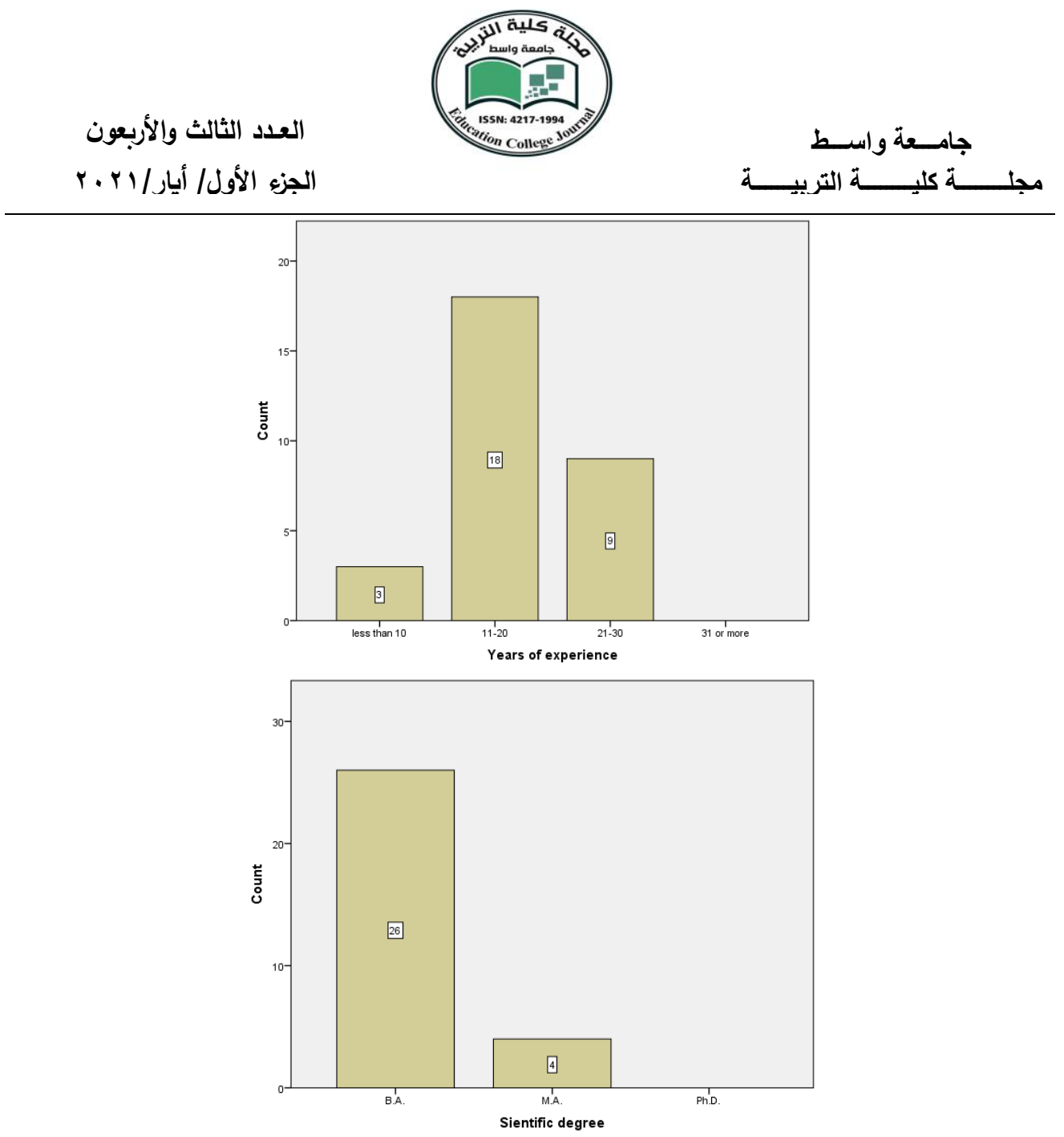

\subsection{Instruments}

The participants were asked to complete a questionnaire containing two parts. In the first part, the teachers' gender, age, years of experience and degree were inquired about, i.e. this provided background information. The second part consisted of 15 Likert scale items with five possible responses (strongly disagree, disagree, neutral, agree, strongly agree) which was aimed at identifying the teachers' perceived difficulties in their use of CLT.

\subsection{Data analysis}

Once the questionnaire had been developed, it was distributed to twelve public and three private secondary schools, with the responses of the teachers being collected over a period of three weeks. Quantitive analysis was undertaken using the SPSS software package, with several statistical tests 
العدد الثالث والأربعون

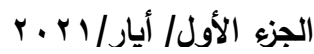
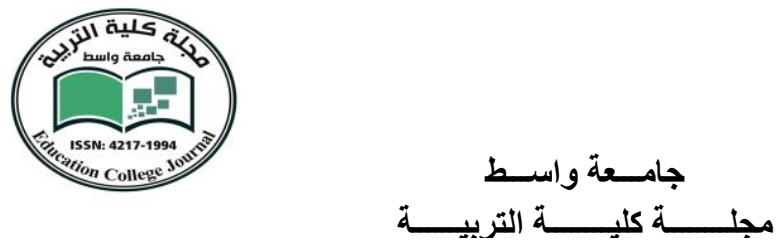

being carried out. First, we investigated whether there were significance differences in the responses with respect to the items of the first part of the survey and found the following.

1) There is no significance difference between the responses of the participants with respect to gender, as the p-value of the two-sample t-test was 0.171 .

Table.1 Participants Ranking of Agree Responses

\begin{tabular}{|l|c|}
\hline Item & Percentage \\
\hline Lack of facilities to support CLT & $97 \%$ \\
\hline Insufficient time of English lesson & $97 \%$ \\
\hline $\begin{array}{l}\text { Classroom environment reduces the possibility of using CLT (size of the } \\
\text { class) }\end{array}$ & $93 \%$ \\
\hline $\begin{array}{l}\text { There are no opportunities available for the students to communicate in } \\
\text { English outside the classroom. }\end{array}$ & $87 \%$ \\
\hline Students are not well prepared for following this approach & $80 \%$ \\
\hline $\begin{array}{l}\text { Classroom discipline in my context makes the } \\
\text { Implementation of CLT more difficult. }\end{array}$ & $73 \%$ \\
\hline The majority of students learn English just to pass the exam only & $73 \%$ \\
\hline Lack of teachers' activities & $63 \%$ \\
\hline Lack of teachers training with native English speakers & $63 \%$ \\
\hline $\begin{array}{l}\text { Students prefer to be taught grammar and vocabulary rather than } \\
\text { communication skills. }\end{array}$ & $57 \%$ \\
\hline Implementing CLT requires too much work for the teacher. & $50 \%$ \\
\hline CLT is not effective in Iraq & $43 \%$ \\
\hline $\begin{array}{l}\text { I feel more comfortable teaching language structures than communication } \\
\text { skills. }\end{array}$ & $37 \%$ \\
\hline CLT is an ambiguous approach to language teaching. & $30 \%$ \\
\hline $\begin{array}{l}\text { The use of CLT does not allow me to cover the syllabus required by } \\
\text { Ministry of Education }\end{array}$ & $27 \%$ \\
\hline
\end{tabular}

2) There is no significance difference between the responses of the participants with respect to age, as the p-value of the ANOVA (analysis of variance) test was 0.07 .

3) There is no significance difference between the responses of the participants with respect to teaching experience as the p-value of the ANOVA test was 0.176 . 


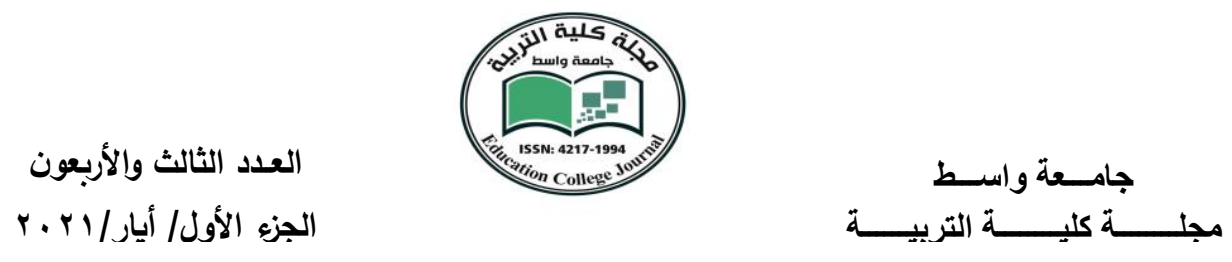

4) There is no significance difference between the responses of the participants with respect to degree level as the p-value of the ANOVA test was 0.245 .

From the above, we can conclude that the responses are consistent according to the background information of the participants. Second, the ranking of participants agree, i.e. strongly agree and agree response, was used to compare the responses of the second part and the results are reported in Table 1.

\section{Results and Discussion}

From Table 1, it can be seen that the vast majority (more than 90 percent) of the participants reported that the main difficulties that they faced when implementing CLT were the lack of facilities, insufficient time for English lessons and the classroom environment. In addition, 80-89 percent of the participants confirmed that using CLT was hindered by the nonavailability of opportunities for the students to communicate in English outside the classroom and that they were not well prepared for studying in this way. 70-79 percent stated that the difficulties were to do with classroom discipline and that the students wanted to learn English just to pass the exam. Meanwhile, 50-69 percent identified lack of teachers' activities, lack of teachers training, students preferring to be taught grammar and vocabulary than communication skills as well as implementing CLT requiring too much work for the teacher, as obstacles to implementing CLT. Finally, the remaining items were not considered as being salient in terms of hindering the delivery of CLT by the participants.

\section{Conclusion}

Teachers using the communicative approach (CLT) need to have a comprehensive understanding of it in order to be able to use it successfully. Those willing to teach English in Iraqi schools through this approach often face difficulties, in particular, the lack of facilities to support it. This was clearly revealed in the responses of the teachers to the questionnaire and the data analysis of this study. The teachers need to focus on the needs, interests, plan their lessons, design materials and time allotted for lectures as well as improving their skills for delivering CLT. Whilst many Iraqi teachers have the desire to use this approach for teaching their students, currently they find 
العدد الثالث والأربعون

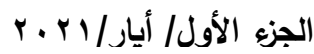

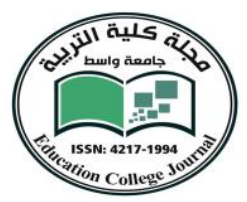

this very challenging. The authorities responsible for administering the education process, e.g. the Ministry of Education, could help them to overcome these difficulties, if they were to promote the effective implementation of CLT in schools.

Moreover, the teaching methods could be improved by adopting a syllabus mainly focusing on the four skills of reading, writing, speaking and listening. Finally, the lesson time for English teaching should be extended in order to allow teachers to select the most appropriate material for their lessons.

\section{References}

1. Abdul Wajid, M. and Saleem, M. (2017). Learner Conformity to Communicative Language Teaching Approach in EFL Contexts: A Case Study in Saudi Arabia. International Journal of Language and Linguistics, Vol. 4, No. 4, pp:240-249.

2. Akram, M. and Mehmood, A. (2011). The need of communicative approach (in ELT) in teacher training program in Pakistan. Language in India, Vol. 11, No. 5, pp;172-178.

3. Bataineh, R. F., Bataineh, R. F. and Thabet, S. S. (2011). Communicative Language Teaching in the Yemeni EFL Classroom: Embraced or Merely Lip-serviced? Journal of Language Teaching and Research, Vol. 2, No. 4, pp. 859-866.

4. Brown, H. D. (1994). Teaching by principles: An interactive approach to language pedagogy. Upper Saddle River, New Jersey: Prentice Hall Regents.

5. Brown, H. D. (2007). Teaching by principles: An interactive approach to language pedagogy (3ed.). New York: Pearson Education, Inc.

6. Chang, S. C. (2011). A Contrastive Study of Grammar Translation Method and Communicative: Approach in Teaching English Grammar. English Language Teaching, Vol. 4, No. 2, pp:13-24.

7. Hiep, P. H. (2005). Imported communicative language teaching: implications for local teachers. English Teaching Forum, Vol. 43, No. 4, pp: 2-9.

8. Huang, S. H. (2016). Communicative Language Teaching: Practical Difficulties in the Rural EFL Classrooms in Taiwan. Journal of Education and Practice, Vol.7, No.24, pp:186-202.

9. Larsen-Freeman, D. (2000). Techniques and principles in language teaching (2nd Ed.). Oxford: Oxford University Press.

10. Littlewood, W. (1981). Communicative language teaching-an introduction. London: Cambridge

11. Mangaleswaran, S. \& Abdul Aziz, A. (2019). The Impact of the Implementation of CLT On Students' Speaking Skills. International Journal of Scientific and Research Publications (IJSRP). Vol. 9, Issue 4, pp:75-82. 


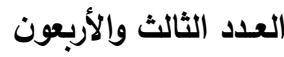

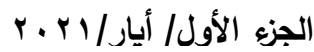

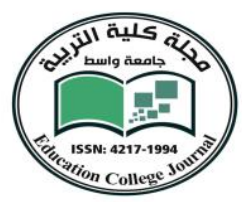

12. Mustapha. S. M. and Yahaya, R. A. (2013). Communicative Language Teaching (CLT) in Malaysian context. Procedia - Social and Behavioral Sciences, 90, pp:788 - 794.

13. Paulista, S. G., (2014). The Application of communicative language teaching: A particular case in a Polish primary school. M.A. thesis, University of Vic.

14. Prieto, J. E. (2008). The role of the teaching staff at present. Its educational and social function. Foro de Educación: Sevilla. Vol. 6, No. 10, pp.325-345.

15. Richards, J. C. (2006). Communicative Language Teaching Today. Cambridge University Press.

16. Richards, J. C. and Rodgers, T. S. (1986). Approaches and Methods in Language teaching: a Description and Analysis. Cambridge: Cambridge University Press.

17. Sekiziyivu, S. and Mugimu, C. B. (2017). Communicative Language Teaching Strategies for German as a Foreign Language in Uganda. Journal of Language Teaching and Research, Vol. 8, No. 1, pp. 8-15.

18. Snow, D. B. (1996). More than a native speaker: an introduction for volunteers teaching English abroad. Alexandria, VA: TESOL.

19. Sreehar, P. (2012). Communicative Language Teaching: Possibilities and Problems. English Language Teaching, Vol. 5, No. 12, pp:87-93.

20. Wei1, L, Lin, H. and Litton, F. (2018). Communicative Language Teaching (CLT) in EFL Context in Asia. Asian Culture and History, Vol. 10, No. 2, pp:1-9.

21. Widdowson, H. G. (1990). Aspects of Language Teaching. Oxford: Oxford University Press.

22. Zhang, J. L. (2006). The ecology of communicative language teaching: Reflecting on the Singapore experience. Innovating English Teaching in China - Selected Papers from the 2006 CELEA annual conference and the 3rd International Conference on CLT in China, 2010 , pp. $32-60$ 